\title{
A traição do falcão: Ángel Rama nos Estados Unidos
}

Pedro Demenech*

Resumo: Este artigo, a partir da leitura do Diario de Ángel Rama (1926-1983), trata da visão desse intelectual sobre os estudos latino-americanos e o ambiente universitário nos Estados Unidos nos anos oitenta, quando ele passou a morar no país. Devido à rápida inserção nas principais universidades, Ángel, além de registrar suas impressões, contrastou a experiência universitária estadunidense com a latino-americana. Por outro lado, nesse país, ele também teve a oportunidade de se reinventar como intelectual, ao ter mais tempo para ler e escrever. Assim, percebemos como esse reconhecido intelectual latino-americano abordou temas como a especialização e o compromisso social da universidade. Ademais, exploro o episódio conhecido como Trampa 28 que resultou na sua expulsão dos Estados Unidos.

Palavras-chave: Ángel Rama; Estudos Latino-americanos; Diario; América Latina; Universidade; Trampa 28.

\section{The falcon and the snowman: Ángel Rama in the United States}

Abstract: Based on the reading of Ángel Rama's Diario, this article deals with Rama's perspective of Latin American studies and the university environment in the United States during the eighties, when he moved to that country. Due to his fast insertion in the main universities, Ángel, contrasted his university experience with the one he had in the Latin American universities, in addition to recording his impressions of the United States. On the other hand, in this country, he also had the opportunity to reinvent himself as an intellectual, having more time to read and write. Thus, we notice how this renowned Latin American intellectual addressed themes such as the university's specialization and social commitment. In addition, the article explores the episode known as Catch 28, which resulted in his expulsion from the United States.

Keywords: Ángel Rama; Latin American studies; Diario; Latin America; University; Catch 28.

Artigo recebido em: 17/10/2017

Artigo aprovado para publicação em: 09/05/2018

\footnotetext{
* Atualmente, com bolsa da FAPERJ, realiza estágio de pós-doutorado no Departamento de História da Pontifícia Universidade Católica do Rio de Janeiro (PUC-Rio), Brasil. Doutor em História Social da Cultura pela PUC-Rio. Este artigo também foi produzido com auxílio da CAPES.
}

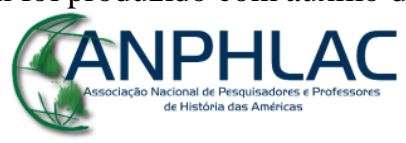




\section{Introdução}

Neste artigo, gostaria de analisar como Ángel Rama (2008), em seu Diario, escrito entre 1974 e 1983, e publicado originalmente em 2001, optou por retratar e descrever a sua estadia nos Estados Unidos, no início dos anos oitenta. Todavia, antes de prosseguir com meu argumento, quero expressar que meu intuito, acima de tudo, foi contribuir com uma análise a respeito de sua inserção na cultura norte-americana, principalmente através da universidade.

Procurei, como Moraña (2006) propôs, prestar atenção ao modo como ele se inseriu nesses espaços (a sociedade e a academia estadunidenses), sobretudo através das entradas que Ángel deixou no Diario. De tal modo, a minha questão dirige-se mais para a maneira como ele construiu e modelou um self ${ }^{1}$ que, aliás, é bem distinto do intelectual público. Meu intuito, assim, foi tentar interpretar a construção social da pessoa de Ángel, ou seja, entender a maneira como ele optou por incorporar, ou não, as experiências que viveu. Para tanto, a leitura de autores como Mauss (2003) e Dumont (1994) que diferenciam "pessoa" de "indivíduo" são fundamentais para circunscrever o debate por mim realizado.

Assim, para construir uma interpretação do Diario, tive de readequar alguns pressupostos teóricos que nortearam minha escrita, pois não seria possível encontrar aquele Ángel que, segundo Aguilar (2010), poderia ser definido como um intelectual da literatura. Lendo o Diario, aliás, vamos encontrar muito pouco a respeito do intelectual que, através das páginas de jornais e revistas, no início da sua carreira como crítico literário e da cultura, principalmente em $M a r c h a^{2}$, explicava não só as identidades social e cultural de seu país e do continente, a partir da interpretação dos elementos narrativos, mas, creio, atuava com a intenção de cultivar o desenvolvimento cultural dos indivíduos e da sociedade como um todo ${ }^{3}$, preparando terreno para que um público, formado

\footnotetext{
${ }^{1}$ Meu intuito, assim, é interpretar a construção social da pessoa de Ángel. Ou seja, entender a maneira como ele optou por incorporar, ou não, as experiências que vivia.

2 Semanário uruguaio que circulou sem interrupções de 1939 a 1974, dirigido por Carlos Quijano (19001984).

${ }^{3}$ Minha visão sobre a ideia e o conceito de cultura é amplamente influenciada pelo que Simmel chamou de a tragédia da cultura. O desenlace dessa tragédia seria que, segundo Simmel (2014), num mundo em que a cultura objetiva cada vez mais ocupa espaço, a cultura subjetiva, isto é, o processo no qual um sujeito se autocultiva, está ameaçada pela objetificação que desvia a sua finalidade última: o aperfeiçoamento do indivíduo por meio daquilo que ele cria.
}

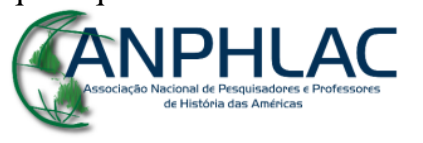


principalmente por leitores, pudesse estar mais próximo dos debates que na época mobilizavam escritores, críticos e demais intelectuais, em particular nos anos sessenta, quando o boom literário e a revolução cubana de 1959 eram os assuntos. ${ }^{4}$

Portanto, para mim, que optei por uma leitura quase que totalmente sincrônica do Diario, embora os temas mencionados acima apareçam com certa frequência, o caráter fragmentado, que é próprio ao gênero do diário, faz com que eles apareçam de maneira pouco sistematizada e, até mesmo, dispersa. Sob essas circunstâncias, diria que é quase impossível abordar de modo sistemático uma discussão exclusiva a respeito de uma rede intelectual ou sobre o que seria a esquerda latino-americana. ${ }^{5}$

De tal modo, mediante a bibliografia que manejei, optei por me referir a Ángel pelo primeiro nome. Fiz isso não porque construí uma intimidade com ele, mas por perceber em meu trabalho que a ideia de distância entre o sujeito/objeto pesquisado e o pesquisador, na verdade, é senão isto: uma ficção que nos permite, inúmeras vezes, controlar aquilo que nos escapa, além de manter superficialmente a aparência de ordem quando, na verdade, não temos a certeza empírica que comprove a realidade da hipótese trabalhada.

Assim, minha reflexão, num primeiro momento, encontrou respaldo nas leituras que fiz de Greenblatt (2005), a respeito da self-fashioning renascentista, e de Clifford (2014), que analisou a questão da automodelagem etnográfica, discutindo como Joseph Conrad (1857-1924) e Bronislaw Malinowski (1884-1942), dois poloneses que viveram parte de suas vidas nas "margens" do império inglês, construíram, de certo modo, as respectivas autoridades que lhes permitiam desenvolver seus trabalhos.

Contudo, ainda em relação ao parágrafo anterior, a minha maior influência, sem dúvidas, foi a leitura que Araújo (2005), em Guerra e Paz, fez da obra de Gilberto Freyre (1900-1987) nos anos trinta, especialmente Casa-Grande \& Senzala. Guerra e $\mathrm{Paz}$, na verdade, ofereceu-me uma perspectiva diferente a respeito da história intelectual

\footnotetext{
${ }^{4}$ A respeito desses dois assuntos, cf. Costa (2013) e Gilman (2012). Ambos os trabalhos oferecem reflexões sobre o papel que intelectuais e escritores, sobretudo aqueles considerados de esquerda, assumiram no decorrer dos anos sessenta e setenta, além de analisar a relação deles com um público que eles, a meu ver, supunham mais amplo.

${ }^{5}$ Gregory (2009) e Espeche (2010), após analisarem as páginas de Marcha, mostram que no interior do semanário havia críticas à ideia de uma esquerda latino-americana unida e concisa. As diferentes posições políticas dos grupos considerados de esquerda, inclusive, nem sempre formavam um consenso. Gregory, especialmente, demostra como as ideias e os debates de esquerda no Uruguai afastaram-se de certa realidade, assim, tornando-se temas impopulares na opinião pública.
}

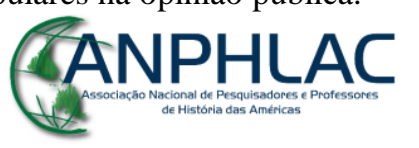


porque, primeiro, ao analisar a obra de Gilberto, como Araújo costumava chamá-lo, não se concentrou apenas no contexto em que ela fora produzida. Sem se descuidar dessa questão, Araújo, na verdade, ainda montou uma segunda perspectiva em que, lendo a obra inserida no seu próprio tempo, procurava resgatar não apenas o sentido que ela tinha ao ter sido escrita, mas qual o novo contexto que poderia ser oferecido através de uma nova leitura.

Então, quando decidi escrever a respeito de Ángel nos Estados Unidos, tendo o Diario como fonte principal, respeitei o máximo que pude as características do gênero analisado. Tratando-se de um texto descontínuo, intervalado e autorreferente, redundante e, ainda por cima, não narrativo, é quase impossível, por exemplo, encontrar, como mencionei acima, o intelectual que costumamos imaginar ao se lembrar de Ángel. De tal modo, a fim de dar sentido à minha hipótese, transformei o Diario numa unidade textual que, de algum modo, pudesse oferecer algumas informações sobre como Ángel procurou viver e trabalhar sua subjetividade nos Estados Unidos.

Na realidade, o Diario foi escrito numa circunstância de exílio e em terras estrangeiras. Depois de 1973, após o golpe de Estado no Uruguai, Ángel jamais retornou à sua terra natal. Além disso, tendo a renovação do seu passaporte negada pelo governo uruguaio, é como se ele perdesse legalmente a cidadania. Devido a esses fatores, o Diario é também uma tentativa de construir uma continuidade em meio a tantas descontinuidades.

Embora seja sempre uma condição triste ${ }^{6}$, o exílio foi um momento produtivo na carreira de Ángel. Na Venezuela, primeiro país em que se estabeleceu, ele deu aulas, escreveu para jornais e, em 1974, ao lado de José Ramon Medina (1919-2010), foi um dos idealizadores da Biblioteca Ayacucho, instituição inicialmente ligada à presidência da Venezuela e dedicada à publicação de obras sobre a cultura e o pensamento da América Latina, exercendo, após a inauguração, o cargo de diretor literário. Não à toa, com mais de quarenta anos, a Biblioteca Ayacucho segue existindo e, mesmo ligada ao governo, resiste a usos, digamos, exclusivamente políticos. ${ }^{7}$

\footnotetext{
${ }^{6}$ Existe, hoje em dia, certa tendência que aproxima o exilado ao nômade conceituado por Deleuze e Guattari em Mil platôs. O nômade, nesse sentido, é mais um conceito filosófico que político porque, diferentemente do exilado, não perde a sua dignidade, uma vez que ele não foi expulso da sua pátria.

${ }^{7}$ Essa é uma hipótese que, com algum esforço, estou desenvolvendo em minha pesquisa que faz parte do estágio de pós-doutorado.
}

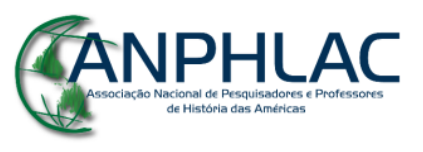


O Diario, em sua maior parte, foi escrito na Venezuela. Contudo, contém a experiência de Ángel fora da América Latina. Na realidade, de modo sutil, é possível enxergar qual o movimento que Ángel faz para sair do continente. São em passagens como a de 26 de outubro de 1978, em que ele anota, não apena a sua frustração a respeito do continente, mas, o desejo de ter uma vida mais estável.

Assim, após retornar de uma viagem da Alemanha para a Venezuela, no aeroporto de Maiquetía, escreveu que se sentia surpreendido pelo golpe imprevisto de ver os taxistas disputando os passageiros e sem respeitar a fila: uma imagem que, construída na intimidade, para além das amarras públicas, permitiu a ele, já reconhecido como intelectual latino-americano, supostamente contrastar a "ordem" alemã com o “caos" latino-americano. É como se nessa anotação de diário tudo se passasse pela gritante diferença que há entre a Alemanha, "donde se han esmerado en cuidar la cualidad de la vida", e o aeroporto de Maiquetía, que aparenta ser, na verdade, uma espécie de metonímia da América Latina, com seus países que optaram por não fazer dessa qualidade de vida um valor comum a todos. De repente, então, surge a ideia de que, na América Latina, segundo o Ángel do Diario, vivemos numa espécie de “torbellino caótico, a empujones y gritos [...] porque todavía [tanto os motoristas de táxi, como a população e os governos] no han razonado que hay más ventajas en un orden de muto consenso" (RAMA, 2008, p. 170).

É importante ressaltar que, tanto em seu trabalho enquanto professor e escritor quanto em sua crítica da cultura, Ángel não tinha o costume de tomar o todo pela parte. Aliás, isso seria demasiadamente simplório para alguém que, naquela altura, já havia escrito alguns livros importantes e possuía conhecimento privilegiado e substancial dos principais textos literários e políticos do continente devido ao trabalho na Biblioteca Ayacucho, além de ter polemizado com figuras como Mario Vargas Llosa (1936) e Pablo Neruda (1904-1973).

Então, numa anotação como a de 26 de outubro de 1978, ao escrever que "El pintoresquismo ya no me compensa del desorden" (RAMA, 2008, p. 170), Ángel, por um lado, assume essa posição porque realiza um juízo que, a princípio, fica para ele mesmo e, por outro, devido a esse caráter pessoal, uma anotação desse tipo não soa nem um pouco como algo estranho. Assim, o diário, embora contenha uma verdade, é um documento que, se colocado no patamar do que se costuma chamar de escrita de si,

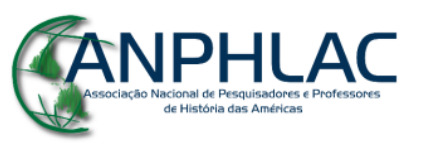

Revista Eletrônica da ANPHLAC, ISSN 1679-1061, №. 24, p. 189-218, Jan./Jun., 2018.

http://revista.anphlac.org.br 
configura-se de modo distinto por, no mínimo, duas razões.

Podemos encontrar a primeira delas num texto seminal para esse tipo de análise: Foucault (1992), a respeito do assunto, jamais mencionou o diário como uma escrita de si. A escrita de si, na verdade, não deveria ser confundida com uma "narrativa de si mesmo", ou seja, um documento que alguém escreve na intimidade sem que, necessariamente, defina qual a função ou o uso mais preciso para ele. Portanto, o diário de Ángel, acima de tudo, nada mais é que uma elaboração da sua subjetividade, descompromissada de regras que, por exemplo, regulam um livro, uma autobiografia, uma entrevista ou até mesmo uma carta mais formal que íntima.

A outra razão é que os diários são, quase sempre, escritos puramente pessoais. Assim, Calligaris (1998), discutindo sobre a história dos diários, afirma que um diarista pode esboçar uma verdade que, de outro modo, jamais poderia dizer. É como se, nesse caso, tudo se passasse fora do tempo histórico, pois, segundo Pachet (1990), para longe dos entraves sociais, o sujeito encontra, ao seu modo, formas de aliviar as tensões e, também, aperfeiçoar-se moralmente - uma espécie de secularização do que, outrora, era uma prática exclusiva da Igreja Católica, esboçada mediante a confissão.

Por isso que, lido historicamente, o Diario pode fornecer elementos para que possamos compreender que para Ángel, num determinado momento, certas escolhas faziam mais sentido que outras. Então, em vez de crer que ele simplesmente considerava a América Latina um lugar pitoresco, cabe, então, analisar de forma mais detalhada essa subjetividade que, aos poucos e de maneira confusa, vai sendo construída dentro de um diário para, dessa forma, conectá-la com elementos mais objetivos e externos como, por exemplo, sua escolha de ir morar nos Estados Unidos.

Tendo mencionado todas as questões acima, agora acredito que seja interessante desenvolver o argumento com a análise do Diario. Todavia, não custa lembrar que, neste artigo, considero o Diario como um depósito das impressões de Ángel e, de tal modo, entendo que esse documento não corresponde necessariamente às aspirações e aos anseios daquele que o escreveu. Sigamos adiante.

\section{CANPHLAC}


"This is not America",

A little piece of you

The little peace in me

Will die (This is not a miracle)

David Bowie

Pouco antes de sair da Venezuela no final de 1978, Ángel abandonaria a escrita do Diario. Nesse intervalo, menos longo que o primeiro (1974-1977), é possível ver que ele realizou todos os planos listados para aquele ano.

Em 1979, Ángel trabalhou como professor visitante na Universidade de Maryland e no Middlebury College. Além disso, conseguiu a bolsa Smithsonian do Programa Latino-Americano do Woodrow Wilson Center for International Schollars, onde iniciou uma pesquisa sobre a cultura latino-americana do período 1750-1830 (RAMA, 2008).

Ainda nesse ano, Carlos Quijano, exilado no México, lançou o primeiro número de Cuadernos de Marcha, revista com a qual Ángel colaborou. A possibilidade de publicar "una Marcha en el exilio" (RAMA, 2008, p. 158) apareceu no Diario em janeiro de 1978, quando Ángel relatou as discussões que mantinha com Quijano desde 1976 a respeito desse projeto.

Como mostrou Garategaray (2015), a decisão de Quijano, ao reunir os exintegrantes e publicar a revista, respondeu à necessidade de construir uma unidade uruguaia fragmentada pelo golpe de 1973. Retomando parte das ideias de Marcha, encerrada pela ditadura no Uruguai, ele e a equipe de marchistas se colocaram no papel de preservar e reconstruir a cultura do país de origem.

No primeiro número da revista, Ángel escreveu um artigo onde afirmava que a cultura uruguaia era feita pelo "pueblo uruguayo que la ha construido empecinadamente a lo largo de la historia y sigue siendo su original productor" (RAMA, 1979, p. 75). Em "Otra vez la utopía, en el invierno de nuestro desconsuelo", ao aproximar o conceito de cultura ao de povo, Ángel enxergou em sua história pessoal a fonte de permanência para assegurar o futuro embotado pelo estado de exceção.

Não à toa, mencionou que qualquer intelectual uruguaio, independentemente do

\footnotetext{
${ }^{8}$ Cada seção deste artigo está precedida por uma parte da letra da canção, escrita por David Bowie e tocada pela banda Pat Methany Group, feita para o filme The falcon and the Snowman (1985).
}

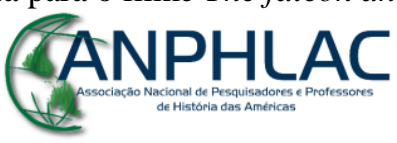

Revista Eletrônica da ANPHLAC, ISSN 1679-1061, №. 24, p. 189-218, Jan./Jun., 2018.

http://revista.anphlac.org.br 
lugar onde estivesse (México, Caracas, Estocolmo, Barcelona, Sidney, Havana), poderia dizer as seguintes palavras:

El Uruguay me hizo, yo soy su producto, para bien y para mal; yo soy hijo de su historia y de su probada vocación de libertad y justicia, yo he sido modelado por su inteligente educación y he sido impregnado de su sentimiento democrático de igualdad, he sido formado en el trabajo y en la exigencia con la convicción de servir una comunidad altiva y laboriosa, he creído en su aspiración a un estado de derecho y por ser fiel a este mandato que atraviesa su historia he tratado de ampliar el reino de la justicia, del mutuo y mejor conocimiento, de la felicidad común, con los recursos a mi alcance. (RAMA, 1979, p. 75)

O trecho acima lembra um juramento: a função do intelectual uruguaio de honrar a democracia. Contudo, longe de ser alguém excepcional, esse intelectual compartilha do "arriscado sentimento" ao integrar o "povo da diáspora" que, naquele momento, vivia no "inverno de seu desconsolo". A questão, contudo, não seria compreender as razões disso que ele chamou de inverno. Tratava-se de algo que denotava o seu horror e a sua perplexidade diante de uma presença supostamente inesperada na cultura uruguaia: a tortura.

Evocando os exames de consciência realizados por intelectuais alemães no exílio, que sentiram o desassossego e o mal-estar do nazismo, Ángel pergunta se a cultura uruguaia que o teria modelado, por

\footnotetext{
¿acaso no ha hecho también a esa falange de repugnantes torturadores que han aplicado las más atroces sevicias, las han estudiado en expertas escuelas extranjeras y las han perfeccionado sobre el cuerpo de sus compatriotas? (RAMA, 1979, p. 76)
}

Com essa pergunta, porém, Ángel afirma que tais "horrores [já] estaban inscritos en el cuerpo de la cultura uruguaya" (RAMA, 1979, p. 76). Quando se manifestam, apenas tornam aparente um "hemisfério oculto" que emerge de modo traumático. Assim, a cultura democrática, da qual os uruguaios se orgulhavam, a qual teria sido uma contribuição "original” para a cultura latino-americana, também gestou esses elementos destrutivos.

Todavia, é simplório supor que o batllismo e a sua planificação excessiva fossem exclusivamente responsáveis por esse hemisfério oculto. Assim, Ángel, sem abrir mão da tradição democrática e do passado uruguaios, mostrou quais "monstros" geraram

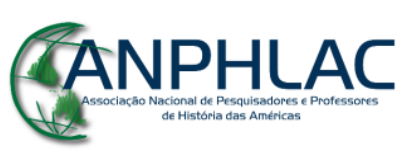


esse trauma na cultura.

Reconhecê-los implicou, em primeiro lugar, a aceitação de que o Uruguai os havia criado. Em segundo lugar, tornou imprescindível redescobrir como utilizar a energia dessa produção para que as "fuerzas profundas de una sociedad" não fossem simplesmente negadas. Por esse caminho, Ángel reescrevia o trauma para liberá-lo de seu aprisionamento.

No campo cultural, essa operação - próxima de como LaCapra (2005) tratou historicamente o trauma -, além da objetividade, vinha carregada de afetos, pois produzia uma alternância entre a representação e a dissociação do que teria sido o Uruguai. Dessa maneira, mais do que reparar o passado, refutar o presente ou simplesmente borrar o futuro, Ángel aceita as circunstâncias para reelaborá-las. Seria o mesmo que, como na primeira entrada do Diario, abrir as feridas secretas da cultura uruguaia para esmiuçá-las.

Numa linguagem próxima da psicanálise freudiana ${ }^{9}$, Ángel analisa o Uruguai a fim de entender os elementos culturais derivados da vida psíquica: o torvelinho, as contradições, as pulsões, os sonhos, com suas graças e seus horrores, que produziram a ambivalência do que para ele foi

[...] el invierno de nuestra autocrítica y que por lo tanto hemos dejado de hablar como niños y actuar como niños, podemos percibir más agudamente cuánto se simplificó nuestra cultura, cuánto se la escamoteó bajo fórmulas operativas aceptables por el campo político, en los últimos años que nos condujeron a la catástrofe [...]. (RAMA, 1979, p. 77)

Embora exilado, Ángel não quis recuperar uma realidade perdida, mas procurou a sua renovação. Desse modo, após a fragmentação, caberia reencontrar "la unidade cultural, verdadero sustento de toda reclamada unidad política" (RAMA, 1979, p. 77). O exílio, então, torna-se o ponto de encontro de uma comunidade dispersa e unificada pela diáspora.

Esses exilados, segundo Ángel, estariam mais unificados e inseridos em outras comunidades, pois conheciam outras histórias e apropriavam-se de tradições diferentes

\footnotetext{
${ }^{9}$ Freud (2011), em $O$ mal-estar na civilização, diagnostica os elementos do mundo moderno que colocam a vida em risco sem necessariamente desconsiderar as vantagens que eles também podem oferecer. Próximo a esse movimento, Ángel, no texto analisado acima, também segue um caminho parecido, agindo tanto como um intelectual que intervém quanto como alguém que elabora uma teoria para o problema colocado.
}

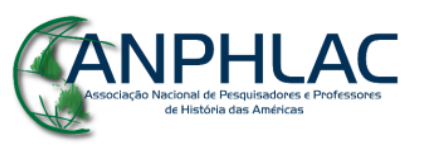


das suas. Assim,

Si para muchos uruguayos conocer la América indígena o la América negra ha sido una revelación que sin duda los favorecerá porque les proporciona un entendimiento más cabal de la pluralidad americana al tiempo que les hace copartícipes de ricas tradiciones intelectuales y artísticas, también ha sido grande la contribución que sus sistemas de referencias y sus percepciones culturales han hecho a las respectivas zonas en que se han instalado. (RAMA, 1979 , p. 80)

Em parte, mesmo que a diáspora prejudicasse a cultura nacional, quem vivia exilado, ao voltar para o Uruguai, teria a chance de transpor uma experiência latinoamericana para as novas gerações. Isso, segundo Ángel, teria a ver com o compromisso de educar os jovens uruguaios, prejudicados por esse inverno que se instaurou.

Preocupado com essa juventude que experimentava uma cultura nacional em vias de dissolução, Ángel, então, fala de seu encontro com a obra de don Pedro Henríquez Ureña. Com Henríquez Ureña, Ángel aprendeu que "nosotros los hombres latinoamericanos sólo podemos existir con una viva consciencia utópica, si por ella se entiende la satisfacción de nuestros apetitos humanos y espirituales" (RAMA, 1979, p. 81).

A redenção da utopia americana mostra que, para Ángel, o futuro da cultura uruguaia passava pela reconstrução do sentimento de latino-americanismo. Essa visão opunha-se ao "nacionalismo provinciano" da ditadura, pois resgatava aquela aspiração ao universalismo que, a seu ver, não prejudicaria em nada o Uruguai. Ao contrário, incutiria num ambiente esterilizado pela violência as energias vivas e criadoras de outrora.

Quando publicou esse texto, Ángel já morava nos Estados Unidos. De tal modo, a partir das ideias de Henríquez Ureña, ele esboçou a possibilidade de reconstrução do Uruguai. Assim, entre 1979 e 1980, à medida que Ángel se insere nos Estados Unidos, é possível identificar uma mudança na forma como ele se vinculava ao latinoamericanismo. Num primeiro momento, essa modificação, de modo bem sutil, passa pela elaboração da linguagem, agora mais acadêmica.

Por isso, no segundo momento, essa variação se liga a uma constatação feita no Diario. Trata-se de sua inserção no que, na anotação de 12 de outubro de 1977, chamou de ghetto universitário: um mundo onde os intelectuais se especializavam. Ao olhar de

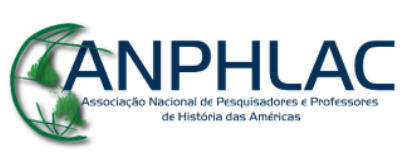


Ángel, os especialistas inseridos nos campi não precisariam se preocupar com a sociedade e nem ter o comprometimento dos intelectuais latino-americanos.

No entanto, Ángel acabou indo para os limites de um campus, de onde imaginava sempre "quedar fuera". Não que ele abandonasse a postura militante; é que, nesse ambiente, uma atitude engajada soaria deslocada. Nesse aspecto, se essa mudança de linguagem é sutil em seus textos acadêmicos, isto é, na maneira de ele fazer a crítica da cultura, no Diario, ela ocorre de forma mais aparente.

A saída da Venezuela, o afastamento geográfico da América Latina e a reaproximação de um passado uruguaio anteriormente abandonado são fatores que implicam na mudança que mencionei anteriormente. Diferentemente do que se passou de 1974 a 1978, Ángel estava agora melhor inserido no meio acadêmico norteamericano. Além disso, as aulas e a bolsa de pesquisa, principalmente, contribuíram para esse aperfeiçoamento intelectual que analisarei na próxima seção.

\section{Fora do charco}

Blossom fails to bloom this season Promise not to stare too long (This is not America) For this is not a miracle

Depois que saiu da Venezuela em 1978, Ángel voltou a escrever no Diario em fevereiro de 1980, num outro caderno, de cor vermelha e capa dura. Entre 1974 e 1978, todas as anotações eram iniciadas com a data. A partir de 1980, quando ele retoma a escrita do Diario, isso muda. Ao que parece, sua preocupação seria a de demarcar mais o espaço do que o tempo de quando escrevia. Na primeira entrada, após $1^{\circ}$ de fevereiro de 1980, está o nome da cidade onde morava: Washington. Nesse mês, com exceção dos dias 24 e 29 , ele anotou apenas a cidade.

Já nas entradas feitas de março a junho, mês da última anotação de 1980, ele parou de marcar a cidade e voltou a contar o tempo, embora sem o cuidado de registrar regularmente as datas. Anota o mês ou o dia da semana, às vezes os dois. Assim, como em novembro de 1978, Ángel vai levando o Diario de forma intermitente.

Quando retoma pela terceira vez o Diario abandonado, Ángel dá a sensação de espacializar o tempo. Talvez, por imaginar que vivia um período de paz, preocupava-se

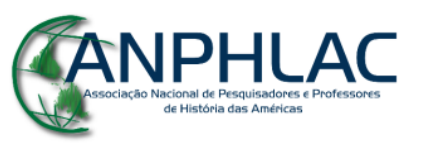

Revista Eletrônica da ANPHLAC, ISSN 1679-1061, №. 24, p. 189-218, Jan./Jun., 2018.

http://revista.anphlac.org.br 
menos com o passar dos dias. De tal modo, em $1^{\circ}$ de fevereiro de 1980, em Washington, afirma:

Ignoro por qué esta anotación, que había previsto hace seis meses, aparece repentinamente hoy. Me levanté temprano [...] y necesité poner urgentemente la fecha en este cuaderno comprado hace un año. (RAMA, 2008, p. 181)

Como mostrou Rosa (2009), entre 1978 e 1980, Ángel muda a postura de si para consigo no Diario. De um "eu” atravessado pelas urgências de se escrutinar no presente, passa a construir outro "eu" mais atado ao futuro, cuidadoso em manter sua vida cadenciada. De tal modo, agora define que suas anotações

No son golpes vallejianos, son remociones que se producen y hay entonces cambios imprevistos, hay, sobre todo, reavivaciones. Todo el problema de estos años radica en mantener una vida interior exaltante. Detectar las emociones. (RAMA, 2008, p. 181)

Assim, o Diario se torna uma espécie de escrita poética, que reaviva o mundo naquilo que vai sendo subscrito. A opção é clara: não designar os dias no ritmo dos golpes vallejianos:

Hay golpes en la vida, tan fuertes... Yo no sé.

Golpes como del odio de Dios; como si ante ellos,

la resaca de todo lo sufrido

se empozara en el alma... Yo no sé!

$[\ldots]$

Esos golpes sangrientos son las crepitaciones

de algún pan que en la puerta del horno se nos quema

¡Y el hombre... Pobre... pobre! Vuelve los ojos, como

cuando por sobre el hombro nos llama una palmada;

vuelve los ojos locos, y todo lo vivido

se empoza, como charco de culpa, en la mirada.

Hay golpes en la vida, tan fuertes... ¡Yo no sé! (VALLEJO, 1979, p. 3)

Indo numa direção contrária à do poema de César Vallejo (1892-1938), Ángel abriria mão da nostalgia. Removendo esses imprevistos e escapando "da ressaca de todo sofrimento", ele procurou compreender melhor o conjunto de suas emoções. De tal modo, ao fazer das reavivaciones um modo de detectar as suas emoções, montou caminhos interiores menos agitados.

Com essa característica, então, ao encontrar a sua irmã, que não via há seis anos, sentia uma mescla de emoção e de rotina desconcertante: "fue como reinstalarse en una

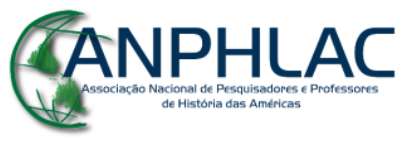


vida corriente, de plática menuda algo rutinaria pero sabrosa” (RAMA, 2008, p. 182). Aos poucos, parece perder a comunicação com o seu passado. Até mesmo numa conversa com Alberto Oreggioni (1939-2001), com quem ele trabalhou na $\operatorname{Arca}^{10}$, o passado parecia "tan fantasmal" que melhor seria não voltar mais ao seu país, pois não tinha um lugar possível, nem era requisitado. Nesses dois encontros, nos quais o passado era revivido por meio de imagens, lembrou que em sua vida

[...] es todo Montevideo, toda mi vida de hecho, lo que no puedo recuperar, lo que se ha ido de mis manos. Esa conciencia, bien dolorosa, es lo que explica mi necesidad de fijar cada día lo que veo y siento, es el origen de esa reacción interior que me susurra, en la calle, en la oficina, "ve esto", "registra esa luz", "conserva ese árbol", "aprópiate de ese rostro", "consérvalo". (RAMA, 2008, p. 183)

Nessas remoções, descobre o que ainda tem e o que perdeu. Com isso, no Diario, guia-se pela necessidade de reconhecer e conservar o que vê e sente. Aos poucos, a melancolia cede lugar ao luto e assim ele coloca suas energias naquilo que está diante de si: "Con la recuperación del ciclo de las estaciones, en USA, también he recuperado la extremada fugacidad del tiempo, mi propio desintegrarme dentro de él, la oscura premonición que dice 'ya es tarde"” (RAMA, 2008, p. 183).

Até então, o Diario respondia à necessidade de reabrir o tempo, supostamente fechado. Porém, quando ele o recupera, é o próprio diarista que se vê desintegrando na sua fugacidade. Pressentindo que seria tarde, e que resultava impossível enganar o texto íntimo, Ángel remonta a sua vida para que nem tudo seja Montevidéu ou o tempo passado.

Assim, nesse reencontro com pessoas da época montevideana, reconhece as suas mudanças físicas. Contudo, ao averiguar o seu "eu", descobre que "nada ha cambiado, sustancialmente, en lo interior, para sorpresa y congoja mía" (RAMA, 2008, p. 183). O tempo já não reside nas mudanças, mas nas permanências.

Por isso, ao refletir sobre esse assunto, anotou que

Vendrán otras explicaciones. Pero esta mirada panorámica de Braudel en Le temps $d u$ monde que estoy leyendo, me es estrictamente afín: los grandes espacios y tiempos manejados amorosamente y dentro de ellos los datos concretos que iluminan, hacen vivo, el movimiento de los hombres, a pesar de

${ }^{10}$ Editora que Ángel montou com seu irmão Carlos Rama.

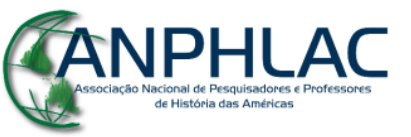

Revista Eletrônica da ANPHLAC, ISSN 1679-1061, №. 24, p. 189-218, Jan./Jun., 2018.

http://revista.anphlac.org.br 
que a estos impulsen fuerzas superiores e incontrolables. (RAMA, 2008, p. 184)

A referência a Braudel no Diario, de quem Ángel foi aluno em Paris, não poderia ser mais oportuna para a minha reflexão. Como esses que manejam o espaço e o tempo públicos, no texto do Diario, isto é, numa escala micro, Ángel ajunta os dados concretos que iluminam e tornam vivos os seus movimentos para atravessar as forças superiores e incontroláveis da vida. Desse modo, desvia-se dos "golpes vallejianos".

$\mathrm{Na}$ intimidade, como anotou em 25 de dezembro de 1977, ele entra dentro de si, e o seu Diario já não diz respeito a mudanças físicas nem a hostilidades, mas à tarefa de espacializar o tempo num âmbito interior que muitas vezes foi deixado de lado. Isso é o que, segundo ele, seria a sedimentação do viver. De tal modo, aceitou ser

la hoja en la tormenta a pesar de rechazar el desorden que la mueve, en la medida en que pueda comprender las fuerzas que actúan y que pueda enamorarme del color, los movimientos, la gracia particular de esas hojas. (RAMA, 2008, p. 184)

Parece que a vida íntima se regula pela subjetividade. Ou seja, é o lugar onde ser como folha na tormenta implica aceitar a beleza imposta pela desordem. Já a vida pública, porém, aparece regulada pela racionalidade que corresponde a

Los dioses terribles y vengativos de antaño [...] que hoy llamamos el capitalismo; tanto en Braudel, como en Wallerstein, es su acción a escala internacional, su magnificencia y la suma de dolor que se ha alimentado, lo que confiere ese aire de imperturbable divinidad vengativa. (RAMA, 2008, p. 184)

Dito isso, a meu ver, escrever o Diario seria como não sucumbir ao que, quatro anos mais tarde, em 1984, ficou conhecido, no primeiro capítulo de La ciudad letrada, como a "cidade ordenada". No ímpeto de tornar a América a terra do futuro, os europeus, fazendo tábula rasa dos povos americanos, supunham que pudessem

[...] negar ingentes culturas - ainda que elas tivessem de sobreviver e infiltrar-se de maneira dissimulada na cultura imposta - e começar ex-nihilo o edifício do que se pensava ser mera transposição do passado, quando na verdade foi a realização do sonho que começa a sonhar uma nova época do mundo. (RAMA, 2015, p. 22)

Como as culturas ingentes da América, submetidas ao jugo externo, ao trabalhar

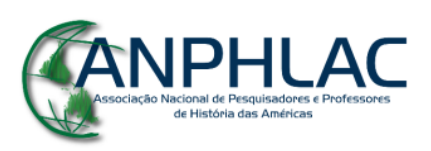

Revista Eletrônica da ANPHLAC, ISSN 1679-1061, №. 24, p. 189-218, Jan./Jun., 2018.

http://revista.anphlac.org.br 
a sua interioridade, Ángel se infiltrou num edifício que pareceu ser ex-nihilo a transposição do passado e desse modo iniciou uma reinvenção de si. O Diario, além da resistência a esse ordenamento, foi a primeira realização material dessa recriação, crucial na modelagem intelectual de Ángel.

Lembrando a aproximação feita entre o Diario e o ensaio (DEMENECH, 2017), percebi que a menção dos nomes de Braudel e Wallerstein tem relação direta com a escrita de La ciudad letrada, pois são autores que Ángel utilizou no livro publicado postumamente. Entretanto, essas aparições no Diario correspondem, primeiro, ao modo como ele rearticula a sua subjetividade e, segundo, ao tipo de linguagem que passou a operacionalizar nos anos oitenta.

Ordenando a si, consequentemente, Ángel dá outra direção ao tempo que, agora, aparece inserido no espaço. Desse modo, o Diario e La ciudad letrada, juntos, ao responderem o que seria esse paraíso idealizado, integraram parte do vocabulário que, nos anos oitenta, correspondeu à redefinição política de um latino-americanismo menos militante e mais afinado com as propostas culturalistas.

O horizonte político da utopia americana estava sendo esvaziado, e a "golpes vallejianos".

Isso, no Diario, está evidenciado num encontro com Vargas Llosa (em Washington, no dia 23) que, naquela época, preparava o livro La guerra del fin del mundo (1981), uma história sobre a guerra de Canudos inspirada em Os Sertões (1902) de Euclides da Cunha (1866-1909). Observando o trabalho de Vargas Llosa, Ángel mencionou que o mais aparente dele, naquele momento, era a fascinação por atitudes fanáticas, as quais simultaneamente o atraíam e o rechaçavam. Esse fanatismo correspondia ao comportamento dos intelectuais e grupos "esquerdistas" latinoamericanos.

Ainda nessa anotação, é feita a primeira menção ao nome de Rodríguez Monegal $^{11}$ (1921-1985) no Diario. Eles se encontraram por ocasião de um jantar em que a escritora Beatriz Guido (1924-1988), que dava aulas no Colorado, numa "de esas

\footnotetext{
11 Ángel e Emir, na realidade, conheceram-se no Uruguai e, desde os anos sessenta, estabeleceram uma rivalidade intelectual que, a meu ver, é comparável àquela que Ridley Scott retrata em Os duelistas (1977). O trabalho de Rocca (2006) em relação a esse assunto detalha não só as opções teóricas de cada um deles, mas a maneira como essa tensão foi sendo esboçada. Gilman (2012) também discorre largamente a respeito da atuação que tanto Ángel quanto Emir desempenharam para consolidar a ideia de literatura latino-americana, considerando a atuação institucional de cada um deles.
}

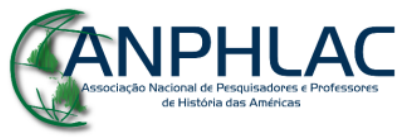


Universidades vacías e inhóspitas”, narrava sobre a vida íntima e a alheia. Isso, porém, fez Ángel reviver "un tipo de intelectual uruguayo de otra época, lo que llamábamos 'pastelero', poco riguroso, sociable, amigable en demasía, sobreviviendo en el medio mediante concesiones, chismoso y escasamente culto" (RAMA, 2008, p. 187).

Alheio ao campus vazio e inóspito, Ángel desprezava os esquerdistas e os pasteleros: dois tipos responsáveis pelo esvaziamento político da utopia americana. $\mathrm{O}$ fanatismo, de um lado, e a falta de rigor, do outro, influenciariam diretamente o declínio e a queda do homem universal latino-americano de Henríquez Ureña, do humanismo de Alfonso Reyes e da síntese de Picón Salas.

Numa leitura atenta do Diario, podemos mapear como esse modelo humanista latino-americano, ao não dividir espaço com os especialistas, seria facilmente suplantado. Como estava escrevendo nos Estados Unidos, Ángel se vê numa posição ambígua. Para usar uma expressão sua, a vida no ghetto universitário norte-americano implicou mudanças na maneira de ele manejar os dias e a própria carreira.

Assim, quando descreve a passagem do tempo, de uma estação a outra, o tom muda: "La primavera viene sigilosamente y ya está entre nosotros. Alegría de esa interior como agua que crece, que me producen los árboles. Congoja de sentir el paso del tiempo: ya queda atrás mi segundo invierno en USA” (RAMA, 2008, p. 188).

\section{Dentro do campus}

A aflição de Ángel em 1980 já não condizia somente com o trauma do exílio. Havia todo um cuidado em como projetar um futuro possível. De tal modo, em sua inserção nos Estados Unidos, ele sentia os seus valores anteriores, de âmbito mais pessoal, serem contrastados com os novos, de índole mais profissional. Assim, uma vez no campus norte-americano, questionava a si “¿por qué [os professores] se dedican a literatura y al arte, si nada tienen que ver orgánicamente, con ellos?” (RAMA, 2008, p. 188-189).

Nessa pergunta, ele retoma a ideia de que a responsabilidade do intelectual é, acima de tudo, nutrir a cultura (DEMENECH, 2017). Assim, morando nos Estados Unidos, dizia se sentir bem "en Stanford, con la loca apasionada de Jean [Franco], el divertido zorro que es Fernando [Alegría] y el desordenado entusiasmo de Joaquim [F.

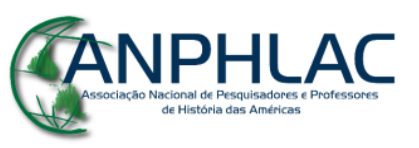


Coelho]", uma instituição onde esse grupo "recuperaba el fervor imaginativo del arte" (RAMA, 2008, p. 189, grifo meu).

No caso da crítica literária, a organicidade e o entusiasmo imaginativo corresponderiam à função criadora que faltaria ao especialista: no Diario, alguém que cultiva uma ordem professoral árida e reducionista, inimiga do belo, do forte e do verdadeiro. Por isso, ao contrastar os ambientes universitários, tendo como parâmetro Stanford, observou que não sentia o mesmo

[...] en Campinas: quizás porque el equipo es joven, porque tiene la gracia brasileña, porque cuando se reúnen lo primero que hacen es arrollar la alfombra para bailar, porque ponen pasión y juegan su vida en lo que dicen. [...] Están vivos en el curso arrollador del arte y el conocimiento: eso es central para ellos, es sentido de la vida. Y las cosas no está separadas, el arte, el deseo, la política, el júbilo y el miedo, son todas cosas que van juntas, con el agregado de que exigen como pago la gracia. (RAMA, 2008, p. 189-190)

A junção dessas esferas da vida caracterizaria o que acima foi chamado de fervor imaginativo da arte: um componente fundamental da utopia latino-americana. Algo, aliás, próximo do que Ángel fez, sem abandonar a perspectiva acadêmica, ao transformar a crítica num serviço público capaz de identificar as obras inseridas nos respectivos processos de produção.

A descrição do Diario delineada até então, em parte, permite pensar um Ángel que resiste à experiência de choque e à fragmentação da vida. Também, aclara que o papel fundamental da instituição universitária seria o de movimentar e o de unificar os diferentes saberes. Assim, ao conviver com os especialistas, ele procurou conservar parte da característica de orquestrar os fragmentos numa totalidade.

Por isso, em relação à etapa estadunidense do Diario, considero fundamental a leitura das anotações de Ángel sobre a universidade. Ele deseja ser, ao mesmo tempo, um intelectual latino-americano engajado e um scholar. De tal modo, quando, na Universidade de Maryland, fizeram-lhe uma oferta para o cargo de senior professor do Departamento de Espanhol, relatou, em seis de março, ser tomado pela "sensación de angustia cuando las cosas se hacen inminentes y aparentemente definitivas" (RAMA, 2008, p. 201). Diante desse convite, que ele aceitaria, fez a seguinte observação:

Me admira el entusiasmo de Saúl Sosnowski para hacer del Department of Spanish un gran centro intelectual. Ha puesto todas sus energías en el proyec-

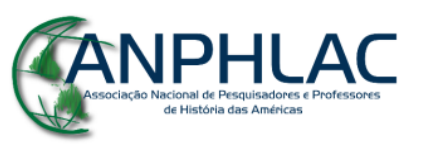


to, sin pararse en que debe rehacer todo como si partiera de cero aunque desgraciadamente no tiene la comodidad de partir de cero. Las carencias bibliográficas, docentes, de recursos de todo tipo, son enormes. Cuenta conmigo para el avance y me es difícil decirle que no son sólo profesores dedicados, sino toda la estructura de sostén lo que es indispensable para que puedan rendir los profesores. (RAMA, 2008, p. 201)

Ainda em 1980, antes de assumir o cargo em Maryland, além das inúmeras conferências e viagens acadêmicas, Ángel lecionou como professor visitante na Universidade de Princeton. No Diario, em oito de março, ao narrar a sua experiência, destacou a sensação de estar num "pueblecito insignificante en torno al campus universitario y del círculo de profesores encerrados y como perdidos del mundo en un ghetto intelectual" (RAMA, 2008, p. 201).

Aprofundando a descrição do ambiente, mencionou a qualidade do corpo docente, reconhecendo-o inclusive como superior ao da Universidade de Maryland e, ainda, anotou a respeito da biblioteca e da solvência das conexões acadêmicas. Essas características, porém, apenas ressaltariam a imagem de um ghetto intelectual que

[...] no obsta al reconocimiento de ese encierro dentro del pueblo, de la universidad, de la disciplina, que registro en casi todos estos organismos. Como si estuvieran fuera de la corriente principal de la cultura del país, contemplándola y examinándola a veces, ignorándola frecuentemente, ligados entre sí con otros ghettos similares en diversos puntos del mundo. (RAMA, 2008, p. 203)

Nessa entrada de oito de março, a palavra 'ghetto' aparece duas vezes. Isso indica, como vemos na citação acima, que a universidade estaria afastada da sociedade, mas conectada a grupos que seriam similares entre si. Desintegrada de seu meio, não poderia automaticamente incorporar a diferença e a diversidade. De tal modo, ao olhar de Ángel, no Diario, a instituição universitária se apresentaria cada vez mais despolitizada e encerrada em si mesma.

Se me baseasse apenas na leitura do diário, as afirmações do parágrafo anterior, em parte, soariam como lugar-comum. Não resta dúvida de que, no texto íntimo, Ángel carregava as tintas. Ademais, ele acreditava que a universidade tinha a missão de fomentar a identidade nacional por meio do desenvolvimento da sociedade, além do papel de integrar as diversas culturas num modelo mais amplo e articulado.

Todavia, chama-me a atenção que, após descrever o ambiente universitário de Princeton, ele tenha feito o seguinte comentário:

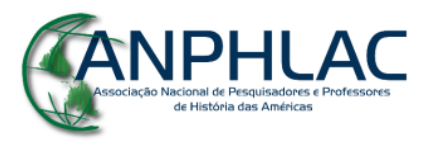

Revista Eletrônica da ANPHLAC, ISSN 1679-1061, №. 24, p. 189-218, Jan./Jun., 2018.

http://revista.anphlac.org.br 
Es, en el fondo, la diferencia con los intelectuales latino-americanos que no han alcanzado ese grado de especialización quizás, y que en definitiva son profesores porque son escritores y a veces por añadidura políticos y cumplen simultáneamente todas las funciones en el centro de la vida social, estatuyendo el principio de reverencia al intelectual como guía, maestro, estudioso, profeta y, en ocasiones, hombre de acción. (RAMA, 2008, p. 202)

Lido dentro do Diario, de forma sincrônica, esse trecho de oito de março de 1980 faria alusão ao intelectual público da entrada de $1^{\circ}$ de setembro de 1974. Agora, numa perspectiva diacrônica, tem relação com o principal argumento de La ciudad letrada, segundo o qual os intelectuais, inseridos nesse "centro da vida social", moldariam as suas comunidades.

Se percebesse o intelectual latino-americano como Ángel em seu livro póstumo, desconsideraria as circunstâncias em que foi feito o enunciado sobre a intelectualidade latino-americana no Diario. Portanto, mais do que entender o letrado como um intelectual integrado organicamente à vida pública, caberia considerar o campo discursivo, os sujeitos e os modos de autorização dessa escrita.

Para Ángel, natural de um país em que, por cento e cinquenta anos (1834-1984), existiu somente a Universidade da República, o mundo universitário norte-americano era, no mínimo, mais amplo. Todavia, o contraste entre os professores norte-americanos, de Princeton principalmente, e os intelectuais latino-americanos corresponde a outra questão.

De tal modo, antes de se efetivar no cargo de professor universitário em 1969, Ángel desempenhou atividades que o colocavam em "la corriente principal de la cultura del país”, principalmente na Biblioteca Nacional do Uruguai. Desse ponto de vista, ele contribuiu diretamente para plasmar uma identidade nacional. Mas, devido à estrutura universitária uruguaia, em relação aos seus colegas norte-americanos, ele tardou para entrar na academia.

Além disso, essa diferença entre o intelectual latino-americano (como guia, mestre, estudioso, profeta e, ocasionalmente, homem de ação) e o professor universitário norte-americano encerrado nos ghettos aborda duas experiências universitárias distintas entre si: uma, responsável por arquitetar a sociedade, entrelaçada à tradição; a outra, mais individualista em relação à esfera pública, guiada pelo utilitarismo.

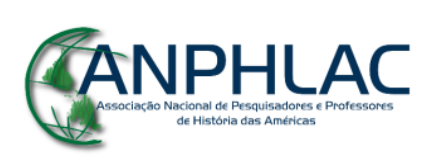


Ramos (2008), por outro lado, mostrou que essa dicotomia, longe de significar a sagração do intelectual, tem conexão com o fortalecimento do Estado e a autonomização dos saberes. No Chile, por exemplo, a centralização nacional da educação, ainda em 1840, implicou em um grau de especialização que contrastou com a “cultura desinteressada” defendida por Rodó, Henríquez Ureña e Reyes.

No caso uruguaio, essa autonomização se consolidou em princípios do século XX com a chegada de Batlle y Ordoñez ao poder. Ainda assim, quando a Faculdade de Humanidades e Ciências foi criada em 1947, a falta de demanda por pesquisadores implicou na formação de professores para o sistema educacional básico. Mesmo após 1967, ano da reforma institucional da Universidade da República, o ensino superior não se transformou substancialmente a ponto de modificar a sociedade uruguaia. Portanto, a universidade no Uruguai, além de ter menor estrutura em relação às dos Estados Unidos, tardou em produzir quadros especializados.

Diante disso, vemos um Ángel revestido da aura redentora latino-americanista a qual, por muitos anos, emanou a crença no papel plasmador atribuído aos intelectuais. Assim, no Diario, quando ressaltou que a diferença entre os modelos latino e norteamericano seria cultural, antes de qualquer coisa, reproduziu parte do argumento que percebe a América Latina como o território da tradição, em oposição aos Estados Unidos. Isso, porém, não implica um desdém dele pelas universidades norte-americanas.

Esse contraste, na verdade, expõe a relação de Ángel com um meio distinto do latino-americano. Por isso, de acordo com a leitura do Diario, é significativo que os seus

[...] lazos de comunicación siempre resulten más prestos y vivaces con los latinoamericanos que con los profesores americanos. Así ahora, con Sylvia Molloy a la que conocí en Princeton y con quien de inmediato tendimos a la red de conocidos comunes y las pasiones regionales, con una presteza y una comodidad que no es comparable a la que exige el trato con colegas americanos, por excelentes que estos sean del punto de vista intelectual o académico. (RAMA, 2008, p. 202)

Substituindo a subjetividade do Diario por coordenadas objetivas, é evidente a dificuldade de inserção de Ángel dentro dos Estados Unidos. Assim, ao encontrar alguém com uma formação cultural similar à sua, tal como Sylvia Molloy, uma argentina, tanto o passado como o presente permitem que ele se costure ao meio onde

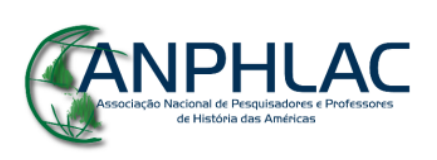

Revista Eletrônica da ANPHLAC, ISSN 1679-1061, №. 24, p. 189-218, Jan./Jun., 2018.

http://revista.anphlac.org.br 
está inserido.

De tal modo, para ele, até então, às voltas com o latino-americanismo, envolvido em múltiplas tarefas, acostumado a não ter estabilidade econômica, a suposta alienação dos professores norte-americanos se traduz na dificuldade pessoal de combinar suas experiências passadas com as do presente. Assim, a estabilidade que Ángel começou a construir nos Estados Unidos, embora fugaz, deu-lhe condições de trabalhar num ritmo distinto ao das etapas montevideana e caraquenha.

No tempo que trabalhou como professor visitante em Princeton, durante quatro meses de 1980, Ángel, além do tempo disponível para estudar, pôde conhecer outras universidades: Harvard (Nova Iorque), Mont Clair College (Newark), Austin (Texas). Nesse momento, mais que em outras épocas, ele também se reinventou como intelectual e sujeito.

Aos poucos, no Diario, um intelectual militante, humanista e latino-americanista começa a dar mais espaço para um sujeito mais ponderado e menos polêmico. Não à toa, após dar uma conferência, Ángel anotou o que sentia a respeito da apresentação de sua formação e da leitura de seu texto "Literatura y clase social" de 1976 feitas por Jaime Alazraki (1934-2014). Refletindo sobre essa situação, escreveu que

\begin{abstract}
En la objetivación que eso produce, en la inquietud que siempre me produce un texto ya publicado hace años, dos pensamientos complementarios asomaron: por un lado la visión que tienen de mí los colegas, considerándome el abanderado de una crítica socioeconómica de la literatura que en principio rechazan pero que en mi caso están dispuestos a mirar con respeto porque no se les ofrece como reduccionista ni empobrecedora del texto artístico; por la otra mi auto-reconocimiento de que esa línea de trabajo que se esfuerza por percibir el arte literario dentro de la cultura y enmarcada en las coordenadas sociales y económicas, me es afín todavía, me permite entender mejor el universo y no empaña mi encuentro con la plena invención del imaginario, probablemente porque a ésta me rindo de inmediato, tengo con ella un contacto siempre fresco y excitante y a partir de él procuro entender por qué se ha logrado, qué expresa, qué conduce. Cada vez más trato de reconocer esa creación dentro de su proposición raigal, lo que implica aceptarla multiplicidad de vías (clases, culturas, filosofías) como igualmente válidas para la consecución del arte. (RAMA, 2008, p. 204)
\end{abstract}

A partir desse momento, no Diario, Ángel começou a se afastar do que chamou, já em 1980, de "ciudad letrada". Desse modo, se em algum momento ele habitou La ciudad letrada, agora, assumia o papel de outsider que, afastado dos que estão "realmente "en la cosa"”, vê-la "desde afuera" (RAMA, 2008, p. 206).

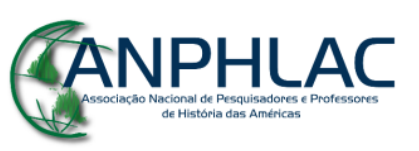


No contexto norte-americano, supostamente mais especializado que o latinoamericano, Ángel toma a visão dos outros sobre si como ferramenta de transformação. Diferentemente do diário escrito na Venezuela, esse texto dos anos oitenta incorpora com mais facilidade as experiências. Assim, sem sentir acossado, em meio à solidão, leva o Diario sem nenhuma imposição: “¿Por qué este cuidado con el Diario? ¿Por qué este gusto por el soliloquio que con él estoy ejerciendo, hasta el punto de [...] aprovechar un tempo libre ocasional para escribir en él?" (RAMA, 2008, p. 209). Esse tempo livre, porém, não foi como seixo rolado.

Em 24 de março de 1980, Ángel recebeu a notícia de que Traba estava com um nódulo em seu seio. Três dias depois, o diagnóstico confirmado era um câncer. De pronto, entre o projeto de iniciar um livro sobre a transculturação e o tempo vazio dos aeroportos, ao pensar nela, anotou:

[Nós] construimos el amor común, paso a paso, por debajo de nuestras respectivas máscaras, con lo que teníamos de mejor y no mostrábamos públicamente, que el amor lo hicieron los "otros" secretos que estaban en nosotros, seres mucho más simples, auténticos y tímidos, que las máscaras brillantes y provocativas que calzábamos. (RAMA, 2008, p. 220)

O abandono progressivo das máscaras, no Diario, encaminha-lhe para um contato mais íntimo consigo mesmo. Dessa forma, nas anotações posteriores à enfermidade de Traba, é como se ele, depois de um longo tempo, encontrasse-se por debaixo do passado encoberto. É nesse encontro que, durante a recuperação de Traba, ele passou a forjar os "sueños de la vigilia, sobre un futuro muy feliz" (RAMA, 2008, p. 224).

Paulatinamente, sua situação nos Estados Unidos, ao longo de 1980, vai ficando mais definida. Ao aceitar a proposta de trabalho na Universidade de Maryland, para janeiro de 1981, Ángel pôs fim ao "dilema venezuelano": afastou-se da Universidade Central e da Biblioteca Ayacucho (RAMA, 2008, p. 226-227). Mais uma vez, então, uma pausa é produzida no Diario.

Desse modo, quando volta a ele em 10 de setembro de 1980, anotou: "Muchas cosas desde mi última anotación [10 de junho]. Reencuentro esta libreta al abrir el equipaje y compruebo que nada he anotado en los últimos meses”. Segue, então,

Fueron 3 meses, compruebo. Al reunirlos, siento que fueron muchas más co-

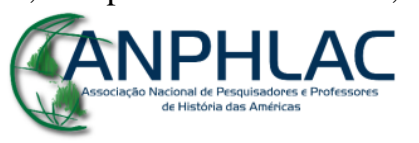

Revista Eletrônica da ANPHLAC, ISSN 1679-1061, №. 24, p. 189-218, Jan./Jun., 2018.

http://revista.anphlac.org.br 
sas que las que imaginaba, aunque todas componiendo un paisaje dislocado, insatisfactorio en su totalidad pero con bellos momentos. [...] Recupero cosas: imágenes, estados de ánimo, conversaciones, simples miradas. Y las pierdo. (RAMA, 2008, p. 239-241)

$\mathrm{Na}$ última anotação de 1980, Ángel parece seguir a premissa da primeira anotação daquele ano. Evitando os "golpes vallejianos", ao procurar por uma vida interior mais calma, produz suas remoções que são vividas entre momentos insatisfatórios e belos. Mas, nessa recuperação que se confunde com a perda, reaparecem os antigos desejos de "Vivir en el jardín donde nacimos, [de] retornar a nuestro paraíso terrenal. ¿Por qué no?” (RAMA, 2008, p. 241).

Quando voltou a Universidade de Maryland, Ángel era professor titular. Inicialmente, essa oportunidade trouxe a estabilidade tão desejada desde a saída do Uruguai em 1972. E, embora desejasse voltar para a terra natal, ele estava se integrando aos Estados Unidos, principalmente a partir do meio acadêmico.

Na única anotação feita ao longo daquele ano, em Washington, em 14 de janeiro, ele anotava que estava longe do Diario:

\footnotetext{
No siento necesidad de él, ni deseo. Lo encontré en el progresivo ordenamiento de los papeles, que voy haciendo desde que dispongo de estanterías y archivadores.

Tampoco tengo tiempo. Como siempre las clases me ocupan mucho tiempo (siempre hay nuevas lecturas) y los compromisos contraídos son tantos que no sé cómo llevarlos adelante. [...]

Pero necesitaba un cuaderno de anotaciones (correspondencia, pagos, etc.) y esté se adapta. Lo seguiré como anotador. (RAMA, 2008, p. 244)
}

A partir dessa data, o Diario se tornou mesmo um caderno de anotações onde ele registrava as cartas que escreveu e enviou.

Em Maryland, durante 1981, Ángel deu quatro cursos: “A Nova Espanha do século XVII: do maneirismo ao barroco"; “Um 'outsider' da narrativa latino-americana: Felisberto Hernández"; "Som, significado e ideologia na poesia"; e "A ensaística hispano-americana do século XIX". Ademais, manteve um ritmo agitado de viagens para congressos, colóquios e conferências. Desde 1980, ele havia ido ao Brasil, ao México e à Venezuela.

Entretanto, em 1982, o Serviço de Imigração dos Estados Unidos negou o pedido de visto de residência que a Universidade havia feito para Ángel. Isso, segundo Peyrou (2008), foi o princípio do fim. A estabilidade proporcionada pela inserção no

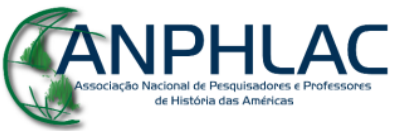


meio acadêmico durou pouco e, mais uma vez, a vida pareceu seguir a golpes vallejianos que lhe expulsariam dos Estados Unidos.

\section{Conclusão: a Trampa 28}

There was a time A storm that blew so pure For this could be the biggest sky And I could have the faintest idea

Snowman melting from the inside Falcon spirals to the ground (This could be the biggest sky) So bloody red, tomorrow's clouds

Devido ao fato mencionado na última seção, Ángel foi declarado "subversivo comunista" por uma lei da época do macarthismo. O governo dos Estados Unidos, através do código 212 (d) (3) (A) (28), evocou a lei de imigração McCarran-Walter, de 1952, que barrava a residência permanente de qualquer pessoa envolvida em atividades do Partido Comunista.

Com 56 anos na época, Ángel, embora tivesse colaborado com atividades ligadas ao comunismo, jamais esteve envolvido diretamente com nenhum partido. Citando o jornal The Nation, em "Dos latinoamericanos en la Trampa 28”, Ángel afirmava que o caso se tratava de uma vendeta política. Para ele, a decisão do governo norte-americano,

[...] no tiene nada que ver con el espantajo del comunista, sino con la descabellada pretensión de regimentar al pensamiento latinoamericano, de crear un precedente para atemorizar a los intelectuales para que no se atrevan a criticar las intervenciones o las exacciones económicas, ni las agencias y corporaciones que se dedican desestabilizar gobiernos legítimamente elegidos por el pueblo. (RAMA, 1982, p. 2) ${ }^{12}$

Não se filiando a nenhum partido, Ángel denunciou tanto as intervenções dos Estados Unidos como as da União Soviética. Isso, porém, foi insuficiente para o serviço de imigração que, ao olhar de Ángel, apenas produziria “interrogatórios

\footnotetext{
${ }^{12}$ Manuscrito mecanografado, em espaçamento duplo, encontrado no Arquivo de Ángel Rama. Série 6, caixa 39, carrapetas 15 e 16. Posteriormente publicado nos seguintes periódicos: Uno más Uno, Quimera, Comunidad, O Estado de São Paulo e Jaque e El Nacional.
} 
fantasmagóricos", "declarações insólitas" e teria "comportamentos despóticos".

Se, por um lado, os intelectuais latino-americanos vinculados ao comunismo não poderiam viajar livremente nos Estados Unidos, por outro, dispunham da União Soviética. Contudo, essa dependência gerou uma dupla exclusividade que, ao final, revelava a incoerência desse sistema persecutório.

Ángel, desse modo, cita o caso de Neruda, que não pôde entrar nos Estados Unidos por vinte e cinco anos. Finalmente, quando permitiram a sua ida, alguns escritores cubanos publicaram uma nota difamatória contra ele. Contudo, alguns dos que assinaram essa nota, viajaram aos Estados Unidos, seja em missões especiais, seja como exilados.

Situações desse tipo apenas realçavam as tensões entre os Estados Unidos e a América Latina. Ainda nos anos sessenta, outros três escritores, sem vínculos com o comunismo, teriam sido enquadrados na "Trampa 28". Os mexicanos Carlos Fuentes (1928-2012) e Leopoldo Zea e o cubano Guillermo Cabrera Infante (1929-2005) que, desde os anos sessenta, rompera com Fidel Castro.

Devido ao desconhecimento da complexidade político-cultural latino-americana, a burocracia estadunidense separava os "bons" dos "maus". Além disso, auxiliada por informantes e pelas ditaduras latino-americanas, desconsiderava, como no caso de Ángel e dos outros três escritores citados acima, a produção intelectual dos "subversivos".

Todavia, a lei McCarren-Walter, ao se referir aos comunistas e anarquistas, não buscava reprimir as ideias, mas comportamentos que colocassem em perigo o estado de direito. Por isso, quando aplicada aos latino-americanos, não levava em conta que na vida política do continente

[...] la subversión del régimen legal, democráticamente elegido, por grupos militares que, una vez instalados por la violencia en el poder, inventan ficciones legales o simplemente encarcelan, torturan y matan los opositores, destruyen los derechos humanos básicos e las garantías democráticas. (RAMA, 1982, p. 4)

Essa lei, então, daria apenas respaldo jurídico aos opositores da democracia. Assim, na América Latina, não seria inconcebível que intelectuais de matizes tão distintos como liberais, católicos, nacionalistas e socialistas trabalhassem ao lado dos

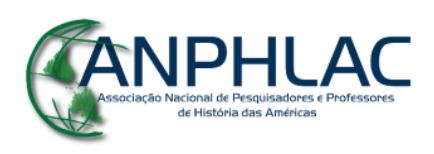

Revista Eletrônica da ANPHLAC, ISSN 1679-1061, №. 24, p. 189-218, Jan./Jun., 2018.

http://revista.anphlac.org.br 
comunistas para reestabelecer o estado de direito. Tal situação, segundo Ángel, ocorreu após 1958 na Venezuela, onde todos os presidentes eleitos democraticamente teriam participado da luta armada que derrubou Pérez Jiménez.

O governo dos Estados Unidos se incomodava com quem se opunha a suas ações no continente. Independentemente de ser comunista ou não, o sentimento de unidade gerado pelo latino-americanismo e o repúdio por qualquer forma de imperialismo fizeram com que Ángel fosse pego pela Trampa 28.

De tal modo, não adiantou que associações como a LASA e o Pen Club, jornais como The Nation e Washington Post, políticos como Belisario Betancur (na época, presidente da Colômbia) e Carlos Andrés Pérez, além de escritores como Cortázar e García Márquez tentassem demonstrar que as acusações a respeito de Ángel eram falsas.

Ainda nesse momento, em outubro de 1982, Reinaldo Arenas (1943-1990) publicou no Noticias de Arte dois artigos acusando Ángel de possuir um passado "comunista" e "subversivo" alinhado ao castrismo. Arenas, que saiu de Cuba pelo porto de Mariel em 1980, sentiu-se prejudicado quando Ángel afirmou que ele fora expulso do país.

Ademais, Rodríguez Monegal, professor na Universidade de Yale desde 1969, além dos cubanos Arenas, Octavio Armand e Cabrera Infante polemizaram com Ángel na imprensa, comprometendo-o diante do Serviço de Imigração. ${ }^{13}$

O processo ficou mais embaraçoso quando o Serviço de Imigração sugeriu que Ángel se declarasse "desertor" do comunismo. Ele, porém, não aceitou formalizar esse esclarecimento e manteve a afirmação de que jamais integrara algum partido. Após isso, alegaram que a sua sentença sairia em noventa dias. Todavia, transcorrido o período, não houve mais nenhum pronunciamento sobre a situação.

Antes de deixar os Estados Unidos permanentemente em fevereiro de 1983, em meio ao imbróglio, ele obteve uma bolsa Guggenheim. Com ela, no período de setembro de 1982 a setembro de 1983, Ángel deu continuidade ao projeto de estudar a história cultural latino-americana entre 1810 e 1900, iniciado com a bolsa do Wilson

\footnotetext{
${ }^{13}$ Todavia, é injusto culpar Emir pela situação de Ángel. Não existem, ainda, estudos conclusivos sobre como a rivalidade entre os dois se estendeu aos campi norte-americanos. Além disso, há indícios de uma polêmica onde Ángel e outros intelectuais latino-americanos eram acusados, por Armand, de excluir os cubanos das discussões sobre o exílio. Ademais, ainda nessa época, tal como relatado no Diario, em 20 de outubro de 1977, os cubanos de dentro e de fora da ilha se envolviam em debates de maneira mais passional.
}

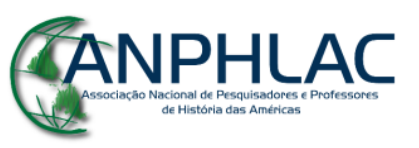


Center em 1979.

No Diario, contudo, não constam registros desse período, quando Ángel, ao desejar uma paz perdida, esteve às voltas com o Serviço de Imigração. Por um momento, como na única anotação de 1981, ele pareceu realmente estar estabelecido no meio estadunidense, alcançando aquilo que almejava.

Desse modo, parecia ter se esquivado dos golpes vallejianos e também parecia manter uma vida interior mais calma, como teria anotado na primeira entrada de 1980. No entanto, embora seguisse trabalhando entre 1981 e 1982, antes de a Imigração negar-lhe o visto, outra vez abandonou o Diario. Assim, as informações que ele produziu sobre esse assunto estão nos artigos e nas cartas que escreveu à época.

O Diario reapareceu exatamente dois meses após a sua saída dos Estados Unidos. Em 20 de abril de 1983, quando ele e Marta haviam se instalado em Paris, Ángel fez o primeiro registro da terceira etapa de seu exílio. Fixando-se num país que já conhecia, anotou que "La inestabilidad, que ha hecho el fondo de mi vida en estos últimos seis meses, persiste, pero el espacio más fijo de la nueva casa, la atempera. Una ficción de hogar, aunque ¿por cuánto tiempo?” (RAMA, 2008, p. 245). A preocupação com a construção fictícia de um lugar para si passava pela sensação de incapacidade, gerada pela renúncia à vida que ele havia escolhido.

A essa altura da vida, Ángel já tinha sido expulso de outros países (Porto Rico, Colômbia e Uruguai) e, agora, com a velhice se aproximando, contabilizava outro "duro golpe no orgulho de se sentir "radiante e duradouro"'. De tal modo, a saída forçada dos Estados Unidos pouco tinha a ver com a burocracia do Serviço de Imigração. "Lo importante", segundo Ángel, "fue la destrucción de un destino trazado y organizado, de una familia afectuosa, de un lugar amoroso" (RAMA, 2008, p. 246).

Com o Diario retomado após a expulsão, o sentimento depositado nele é o de perda. Assim, é sempre a destruição de um destino traçado e organizado que lhe obriga a ficcionalizar um lugar onde encontre o afeto e o amor. Ambos, aliás, auxiliam-no a recuperar o futuro subtraído de um presente que, cada vez mais, torna-se infinito e insuportável.

Ora, nessa circunstância, a mudança não significava transformação, mas a reafirmação de não ter alcançado aquilo que desejava. Então, restar-lhe-ia a sensação de que a sua imagem continha "el aire desvaído que proporcionan en las fotos los cabellos

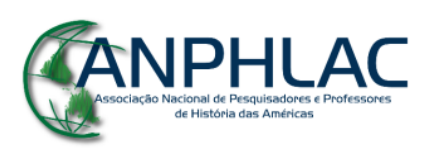


blancos, atestiguando que se está del otro lado de las pasiones incendiadas" (RAMA, 2008 , p. 246). Isso, todavia, nada teria a ver com a força interior e com o desejo que lhe auxiliariam a superar essa circunstância.

Embora a mudança tenha esses dissabores, dado o "fluir desintegrador" da vida, enfrentá-la é a condição necessária para "recuperar uma nova estabilidade" e "encontrar um projeto de vida satisfatório". Desse modo, no Diario, Ángel parece se revestir de um novo disfarce, com o intuito de encarar um destino em que, segundo ele, "não parece restar tempo".

Prestes a completar cinquenta e sete anos, Ángel nos remete à percepção de que o tempo e o espaço lhe faltavam, pois, para ele, "só era reservado o sonho da vigília", no qual se isolaria do mundo para construir outro sonho que lhe permitisse reparar as perdas sofridas. Então, na última anotação do Diario, feita em dois de maio de 1983:

\begin{abstract}
El pasado empieza a pesar menos.
Descubro que ha pasado un día entero y no me he acordado de Washington ni de Maryland, sobre todo no he sufrido.

Cuando me escriben que llame al abogado [...] necesito cobrar fuerzas, pero una vez establecida la comunicación, compruebo que tratar jotra vez! del viejo asunto no me angustia como antes.

Creo que una vez que esté metido en mi trabajo de lleno y comience a generar nuevos proyectos, se irá cicatrizando mi sensación de malestar. [...]

Haber estado bajo un poder despótico y deprecativo, ejercido por gentes inferiores. Lo que me faltaba en el conocimiento de las "entrañas del monstruo". (RAMA, 2008, p. 247)
\end{abstract}

À medida que ia se fixando num novo lugar e no seu trabalho, apaziguando o mal-estar, retomava o controle do presente, escrevendo páginas menos melancólicas em seu Diario. Tentando cicatrizar as suas feridas, retoma a construção de um "eu" vinculado ao latino-americanismo. De tal modo, ao evocar sua situação nos Estados Unidos, modela a linguagem, citando uma frase de Martí relacionada ao imperialismo escrita em 1895: "Viví en el monstruo, y le conozco las entrañas: — y mi honda es la de David" $" 14$.

É significativo que, na última anotação do Diario, Ángel tenha retomado a imagem do intelectual moderno, dado à tragédia e ao combate às forças exteriores. Até o último instante, ele enfrentou o poder despótico que, desde 1973, o empurrava para a degradação. Assim, pode-se supor que não foi a morte prematura que o impediu de

${ }^{14}$ A frase pertence à última carta de Martí ao seu amigo Manuel Mercado.

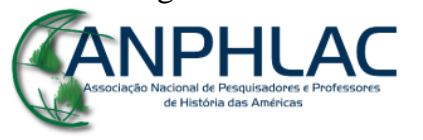

Revista Eletrônica da ANPHLAC, ISSN 1679-1061, №. 24, p. 189-218, Jan./Jun., 2018.

http://revista.anphlac.org.br 
continuar a escrita do texto íntimo, mas o compromisso de manter a sua integridade, mesmo quando essa lhe era negada.

\section{Bibliografia}

AGUILAR, Gonzalo. Los intelectuales de la literatura: cambio social y narrativas de identidad. In: ALTAMIRANO, C. (Org.). Historia de los intelectuales en América Latina: II - Los avatares de la "ciudad letrada" en el siglo XX. Buenos Aires; Madrid: Katz, 2010.

ARAÚJO, Ricardo A. Benzaquen de. Guerra e paz: Casa-Grande \& Senzala e a obra de Gilberto Freyre nos anos 30. $2^{\mathrm{a}}$ ed., São Paulo: 34, 2005.

CLIFFORD, James. A experiência etnográfica: antropologia e literatura no século XX. Tradução de Patrícia Farias. $4^{\text {a }}$ ed., Rio de Janeiro: UFRJ, 2014.

COSTA, Adriane V. Intelectuais, política e literatura na América Latina: o debate sobre revolução e socialismo em Cortázar, García Márquez e Vargas Llosa. São Paulo: Alameda, 2013.

DEMENECH, Pedro. Velhos e novos mundos: Ángel Rama em seu Diario (1974-1983). Rio de Janeiro, Tese de Doutoramento, Pontifícia Universidade Católica do Rio de Janeiro, 2017, 248f.

DUMMONT, Louis. German Ideology: from France to Germany. Chicago: The University of Chicago Press, 1994.

ESPECHE, Ximena. Marcha del Uruguay: hacia América Latina por el Rio de la Plata. In: ALTAMIRANO, Carlos. (Org.). Historia dos intelectuales en América Latina: II Los avatares de la "ciudad letrada" en el siglo XX. Buenos Aires; Madrid: Katz, 2010.

FOUCAULT, Michel. A escrita de si. In: O que é um autor? Lisboa: Passagens, 1992.

FREUD, Sigmund. O mal-estar na civilização. Tradução de Paulo César de Souza. São Paulo: Cia. das Letras, 2011.

GARATEGARAY, Martina. La unidad del exílio: las revistas Cuadernos de Marcha y Controversia en Mexico. Revista eletrônica da ANPHLAC, São Paulo, n. 19, p. 186-207, jul./dez. 2015.

GILMAN, Claudia. Entre la pluma y el fusil: debates y dilemas del escritor revolucionario en América Latina. $2^{\mathrm{a}}$ ed. ampl., Buenos Aires: Siglo XXI, 2012.

GREENBLATT, S. Renaissance Self-fashioning: from More to Shakespeare. Chicago: The Chicago University Press, 2005.

GREGORY, Stephen. Intellectuals and left politics in Uruguay, 1958-2006: frustrated dialogue. Eastbourne: Sussex Academic Press, 2009.

LACAPRA, Dominick. Escribir la historia, escribir el trauma. Trad. Elena Marengo. Buenos Aires: Nueva Vision, 2005.

MAUSS, Marcel. Uma categoria do espírito humano: a noção de pessoa, a de "eu". In:

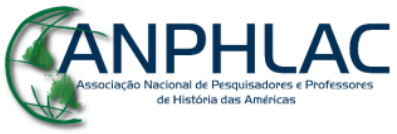

Revista Eletrônica da ANPHLAC, ISSN 1679-1061, №. 24, p. 189-218, Jan./Jun., 2018.

http://revista.anphlac.org.br 
MAUSS, Marcel. Antropologia e sociedade. Tradução de Paulo Neves. São Paulo: Cosac \& Naify, 2003.

MORAÑA, Mabel (Ed.). Ángel Rama y los estudios latinoamericanos. $2^{\mathrm{a}}$ ed., Pittsburgh: Instituto Internacional de Literatura Iberoamericana, 2006.

PEYROU, Rosario. Prólogo. In: RAMA, A. Diario: 1974-1983. Buenos Aires: El Andariego, 2008.

RAMA, Ángel. A cidade das letras. Boitempo: São Paulo, 2015.

RAMA, Ángel. Diario: 1974-1983. Montevideo: Trilce, 2008.

RAMA, Ángel. Dos latinoamericanos en la Trampa 28. [S.l.: s.n.]. 1982.

RAMA, Ángel. Otra vez la utopía, en el invierno de nuestro desconsuelo. Cuadernos de Marcha, Montevideo, 2. época, año I, n. 1, p. 75-81, mayo/jun. 1979.

RAMOS, Julio. Desencontros da modernidade na América Latina: literatura e política no século XIX. Tradução de Rômulo Monte Alto. Belo Horizonte: UFMG, 2008.

ROCCA PESCE, Pablo Hugo. Ángel Rama, Emir Rodríguez Monegal y el Brasil: dos caras de un proyecto latinoamericano. 2006. Tese (Doutorado em Língua Espanhola e Literaturas Espanhola e Hispano-Americana) - Faculdade de Filosofia, Letras e Ciências Humanas, Universidade de São Paulo, São Paulo, 2006.

ROSA, Sandro R. O Diario de Ángel Rama: a vítima e o carrasco. Florianópolis, Tese de Doutoramento, Universidade Federal de Santa Catarina, 2009, 247f.

SIMMEL, Georg. O conceito e a tragédia da cultura. SOUZA, J.; ÖELZE, B. Simmel e a modernidade. $2^{\mathrm{a}}$ ed. revist., Tradução de Sebastião Rios. Brasília: UnB, 2014.

VALLEJO, César. Obra poética completa. Caracas: Biblioteca Ayacucho, 1979.

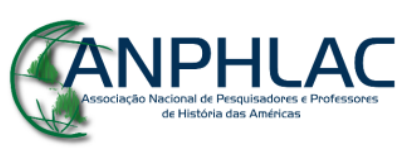

Revista Eletrônica da ANPHLAC, ISSN 1679-1061, №. 24, p. 189-218, Jan./Jun., 2018.

http://revista.anphlac.org.br 